\title{
In Vitro Effects of Extracorporeal Shockwave Therapy (ESWT) on Proliferation and Metabolic Activity of Adult Human Keratinocytes
}

\author{
Christian Ottomann MD1, Vlado Antonic PhD²*, Sandra Münch ${ }^{3}$, Claudia Belfekroun ${ }^{3}$, Gerald Niedobitek MD ${ }^{4}$, Beate Petschke ${ }^{5}$, Mark D \\ Smith $\mathrm{MD}^{5}$, Richard Thiele $\mathrm{MD}^{6}$, Wolfgang Schaden $\mathrm{MD}^{7,8}$ and Bernd Hartmann $\mathrm{MD}^{3}$
}

${ }^{1}$ Universitätsklinikum Schleswig-Holstein Campus Lübeck, Sektion Plastische Chirurgie, Intensiveinheit für Schwerbrandverletzte, Lübeck, Germany

${ }^{2}$ University of Maryland School of Medicine, Radiation Oncology, Baltimore MD, USA

${ }^{3}$ Unfallkrankenhaus Berlin (UKB), Zentrum für Schwerbrandverletzte mit Plastischer Chirurgie, Berlin, Germany

${ }^{4}$ Unfallkrankenhaus Berlin (UKB), Institut für Pathologie, Berlin, Germany

${ }^{5}$ Deutsches Institut für Zell- und Gewebeersatz (DIZG), Berlin, Germany

${ }^{6}$ Internationals Stosswellenzentrum Berlin (IZB), Berlin, Germany

${ }^{7}$ AUVA-Trauma Center Meidling, Vienna, Austria

${ }^{8}$ Ludwig Boltzmann Institute for Experimental and Clinical Traumatology and Austrian Cluster for Tissue Regeneration, Vienna, Austria

\begin{abstract}
Background: The objective of the presented study is to investigate in vitro effects of low energy extracorporeal shockwave therapy (ESWT) on the keratinocytes and their metabolic and proliferative properties for their therapeutic applications.

Materials: Primary culture of keratinocytes was isolated from clinical samples and after passaging into 12 flasks exposed to the various number of ESWT impulses ( $n=25,50$ and100impulses) in combination with several frequencies $(1,3$ or $5 \mathrm{~Hz})$ and distances from the applicator head $(5,6$ or $7 \mathrm{~cm}$ with corresponding energy flux densities $(E F D)=0.04$, 0.025 and $0.015 \mathrm{~mJ} / \mathrm{mm}^{2}$, respectively) using modified water bath at constant temperature $37^{\circ} \mathrm{C}$. Flasks were assigned to receive one combination of treatment parameters. The individually tested distances/EFD with the various impulse numbers and frequencies were summarised to experimental series. Cell viability was measured using trypan blue, cell cytotoxicity was measured using lactate dehydrogenase assay, and cell metabolic activity was measured by level of glucose metabolism.
\end{abstract}

Results: Our results indicate that low energy ESWT has both cytotoxic and stimulating effects on the keratinocytes. These effects depend on number of impulses, distance from the applicator head, and frequency. A proliferationstimulating effect and a higher viable cell count could be observed for a distance of $5 \mathrm{~cm}$ with 100 impulses at $1 \mathrm{~Hz}$ and $\mathrm{EFD}=0.04 \mathrm{~mJ} / \mathrm{mm} 2$.

Conclusion: Our results indicate that ESWT $(E F D=0.04 \mathrm{~mJ} / \mathrm{mm} 2,100$ impulses, $1 \mathrm{~Hz}$ at $5 \mathrm{~cm}$ ) augmented proliferative capacity of keratinocytes in vitro. These promising results grant further investigation and have practical potential in keratinocyte research and production.

\section{Introduction}

Modern wound dressings engineered to promote wound healing often contain living cells [1,2]. Various cell types such as adipocytes, fibroblasts, mesenchymal stem cells, and keratinocytes have been successfully used in wound healing. Keratinocytes have been used in the form of spray in preclinical animal study as well as in clinical trial for severe burns [3-5]. In the animal study directly comparing cryopreserved allogenic keratinocytes and cadaver full thickness skin grafts, authors reported faster epithelialisation in the keratinocytetreated group, with no difference in comparison with full thickness grafts by the end of the study [6,7]. These reports provide a rationale for the further investigation of keratinocytes in wound healing, as well as need for development of cultivating protocols that will decrease culturing time. Augmenting proliferation capacity of the isolated, allogenic keratinocytes will allow clinicians and researchers to produce a sufficient number of viable keratinocytesin a short period of time for their use in wounded patients [7]. Mechanotransduction is a wellknown phenomenon of cellular responses to the physical forces such as sheer stress or stretching both in vivo and in vitro [8-10]. Keratinocytes, cells on the surface of the skin, are constantly exposed to various mechanical stimuli. In vitro keratinocytes respond to the different mechanical stimuli by changes in ERK1/2 pathway and activation of Akt pathway [11]. Sheer stress has anti-apoptotic effects in cultured keratinocytes [12].
Extracorporeal shockwave therapy (ESWT) initially developed as a treatment for disintegration of kidney stones, swiftly expanded from applications in urology to orthopaedic, to soft tissue implications [13-15]. Shockwaves are sonic pulses characterized by a high peak pressure $(500 \mathrm{mbar})$ short life cycle $(10 \mathrm{~ms})$, fast pressure rise $(<10 \mathrm{~ns})$, broad frequency spectrum $(\mathrm{Hz})$ and the generation of stress forces upon interaction with interface [14]. Energy Flux Density (EFD [mJ/ $\left.\mathrm{mm}^{2}\right]$ ) is the most commonly used parameter to describe shockwaves and represents the energy that flows through the area perpendicular to the shockwave propagation. Along with their applications in

*Corresponding author: Vlado Antonic Ph.D, Research Associate, Division of Translational Radiation, Sciences, Department of Radiation Oncology, University of Maryland School of Medicine, 685 W Baltimore, Street, MSTF 7-00A, Baltimore, MD 21201, USA, Tel: 301-768-8750; E-mail: VAntonic@som.umaryland.edu

Received: October 24, 2015; Accepted: November 03, 2015; Published: November 30, 2015

Citation: Ottomann CMD, Antonic V, Münch S, Belfekroun C, Niedobitek GMD et al. (2015) In Vitro Effects of Extracorporeal Shockwave Therapy (ESWT) on Proliferation and Metabolic Activity of Adult Human Keratinocytes. J Bioengineer \& Biomedical Sci 5: 171. doi:10.4172/2155-9538.1000171

Copyright: $\odot 2015$ Ottomann CMD, et al. This is an open-access article distributed under the terms of the Creative Commons Attribution License, which permits unrestricted use, distribution, and reproduction in any medium, provided the original author and source are credited. 
Citation: Ottomann CMD, Antonic V, Münch S, Belfekroun C, Niedobitek GMD, et al. (2015) In Vitro Effects of Extracorporeal Shockwave Therapy (ESWT) on Proliferation and Metabolic Activity of Adult Human Keratinocytes. J Bioengineer \& Biomedical Sci 5: 171. doi:10.4172/21559538.1000171

Page 2 of 8

clinics, ESWT was applied in animal models of soft tissue injuries, burns [16-18], ischemic isografts [19,20], incisional wounds, and models of compromised wound healing such as diabetic wounds[21]. Investigations of mechanisms of action for the beneficial effects of ESWT led to reports of application of ESWT in vitro [22-27]. These studies indeed contributed toward improved understanding of biological effects of ESWT. However, they opened a new application for the use of ESWT in tissue engineering as they demonstrated augmented proliferation of treated cells, increase in cell membrane permeability and changes in cell culture secretome.

The objective of presented study was to determine the response of the cultured adult human keratinocytes after several doses of ESWT. We sought to evaluate effects of ESWT on metabolic activity and cytotoxicity of cultured human keratinocytes. Of particular interest was to investigate whether a reduction in the cultivation time of keratinocytes could be achieved through the application of extracorporeal shockwaves.

\section{Materials and Methods}

\section{Keratinocyte isolation and cultivation}

Human split-skin biopsies prepared for the experiments were obtained from routine plastic surgical interventions carried out at the Centre for Serious Burns \& Plastic Surgery, Emergency Hospital Berlin after approval by the Berlin Ethics Committee and after procurement of informed consent from the patients.

Prior to the isolation of keratinocytes from human split-skin biopsies, to ensure sterility, each split-skin biopsy was subjected to five successive washes ( $3 \mathrm{x}$ washing in $50 \mathrm{ml}$ DMEM / Hams F12 (1:1) + $1 \mathrm{ml}$ gentamicin and $2 \mathrm{x}$ washing in $50 \mathrm{ml} \mathrm{PBS}+1 \mathrm{ml}$ gentamicin) to remove any adherent bacteria. Epidermis and dermis were then separated using Dispase II ${ }^{\circledR}$ (Roche Diagnostics, $\mathrm{GmbH} ; 2.5 \mathrm{U} / \mathrm{ml}$ ). Using a trypsin / EDTA solution (Biochrom AG), the keratinocytes were then separated from the other epidermal cells in the cell complex. Cultivation and passaging of keratinocytes was done according to published protocol [28]. When confluent monolayer was achieved ESWT were applied in predetermined treatment parameters or left untreated in control flasks.

\section{Shockwave device and ESWT treatment}

The OrthoWave $180 c^{\circ}$ ESWT generator (MTS Europe GmbH) was used for all conducted experiments with a constantly set energy flux density (EFD) of $0.1 \mathrm{~mJ} / \mathrm{mm}^{2}$ ("low energy", energy level 5). Shockwaves were produced using the general CP 155 parabolic reflector. Energy of the shockwaves decreases with the distance from the ESWT applicator. The individual energy flux densities for the series of distances from 40 $\mathrm{mm}$ to $70 \mathrm{~mm}$ from the applicator were calculated and measured (data not presented). For the starting EFD $=0.1 \mathrm{~mJ} / \mathrm{mm}^{2}$ on the experimental position of the flasks at 50,60 and $70 \mathrm{~mm}$ from the applicator, respective actual EFD of $0.04,0.025$ and $0.015 \mathrm{~mJ} / \mathrm{mm}^{2}$ were determined. All the ESWT exposure was conducted in the modified heated water bath at constant temperature of $37^{\circ} \mathrm{C}$ filled with $2.500 \mathrm{ml}$ preheated water $[28,29]$.

Experimental groups were generated by combining predetermined experimental parameters: 1)number of shockwave impulses $(n=25$, $50,100,300$ and 600$), 2)$ frequency $(1,3,5 \mathrm{~Hz})$ and 3$)$ distance from the cell culture flasks to the applicator $(5,6,7 \mathrm{~cm})$. After shockwave treatment, the excess medium in the cell culture flasks was discarded and the keratinocytes were then cultured further under standard conditions. The individually tested distances with the various impulse numbers and frequencies were summarised to experimental series. All the experiments were carried out in triplicates.

\section{Cell morphology}

Cell morphology was evaluated using light microscopy. Images of the cell monolayers were obtained using a Zeiss AG, Olympus AG, (Leica Microsystems $\mathrm{GmbH}$ ) inverted microscope and documented by photography using the Axioskop 2 Plus (Carl Zeiss Jena GmbH) on 10x magnification. Image analysis was performed using Image J software.

\section{Quantitative assays: Studies of the cell viability, toxicity and activity}

Viability: The cell concentration was determined microscopically by counting the number of cells in a defined volume within the Neubauer counting chamber. Viable and apoptotic cells were counted using trypan blue (Biochrom AG) and cell viability/apoptosis was presented as total number of cells.

Cytotoxicity: Cytotoxicity was determined using LDH activity assay, ("Cytotoxicity Detection Kit" of Roche Diagnostics $\mathrm{GmbH}$ ) on a microplate reader per the manufacturer's instructions. Briefly, to determine the extracellular LDH activity, the culture supernatants were taken from the cell culture flasks in defined time intervals. The measurement was performed in a 96-well plate at $450 / 690 \mathrm{~nm}$ in triplicates.

Metabolic activity: Metabolic effects of the ESWT in each experimental group were quantitatively determined through the measurement of glucose content in the individual flask supernatants using Glucose HK Gen. 3 (GLUC3) kit (Roche Diagnostics GmbH) according to the manufacturer's instructions. To quantitatively determine lactate released in the keratinocyte culture supernatants, we used enzymatic colorimetric assay, Lactate Gen.2 (Roche Diagnostics $\mathrm{GmbH}$ ) according to manufacturer's instructions.

\section{Statistical analysis}

The analysis of all raw data was performed using the program MSExcel 2003. For statistical analysis the Student's t-test (two-sample, twosided distribution) and F-test for analysis of variance were used. The significance level of $\mathrm{p}<0.05$ was considered significant.

\section{Results}

\section{Cell morphology}

Perforations in keratinocyte monolayer with hanging remnants of cell complexes as well as altered configurations of keratinocytes within the cell complexes could be observed after application of high number of impulses. Treatment with 300 and 600 impulses at all distances and frequencies caused severe disruptions in the cell monolayer and were excluded from further discussions.

For the same number of impulses, increasing distance from the cell culture flasks to the ESWT applicator, the size of the holes formed within the cellular complexes was reduced so that the largest area perforations were observed in the experiments carried out at a shockwave distance of $5 \mathrm{~cm}$. For the same distance, $5 \mathrm{~cm}$ from the applicator, increasing impulse number and increasing frequency lead to increase in the diameters of the perforations formed within the cellular layer. The perforations were initially only microscopically visible with impulse counts of up to 100 and a frequency of $3 \mathrm{~Hz}$. In experimental group receiving 100 impulses at $5 \mathrm{~Hz}$, and all frequencies at 300 and 500 impulses, the perforations became macroscopically visible with 
Citation: Ottomann CMD, Antonic V, Münch S, Belfekroun C, Niedobitek GMD, et al. (2015) In Vitro Effects of Extracorporeal Shockwave Therapy (ESWT) on Proliferation and Metabolic Activity of Adult Human Keratinocytes. J Bioengineer \& Biomedical Sci 5: 171. doi:10.4172/21559538.1000171

diameters ranging from $0.2 \mathrm{~cm}$ to $0.8 \mathrm{~cm}$ (Figure 1 and $1 \mathrm{~A}$ ).

When exposed to lower number of impulses (50 and 25 impulses) at any frequency and distance, no visible perforations were observed. Small perforations formed in the cell layer almost completely disappeared within the subsequent cultivation period of 7 days. The cell complex remnants on the outskirts of the perforation remained preserved and overlaid the newly formed adherent cell complex. Within the cell layer, in addition to perforation, an altered arrangement of keratinocytes within the cellular complex could be seen over the cultivation period, which near the flask rim were observed to be drifting wavy-like or compressed (Figure 1B).

Morphologically, the keratinocytes were seen to be both stretched and compressed. Over the subsequent cultivation period of 7 days post ESWT there were further morphological differences between the treated - ESWT group and untreated keratinocytes - control group (Figure 2). While the untreated keratinocytes were of similar size and shape within the cellular complexes, the keratinocytes in the ESWT cell culture flasks were heterogeneous in size and shape. In addition to a high proportion of small, rounded cells in the basal area of the flask as well as at the flask rims, there were also relatively large cells in the newly-formed overgrown perforation area. The cells had oval, central nuclei of uniform size with distinct nucleoli. Occasionally, mitoses were visible (Table 1).

\section{Cell viability}

The absolute viable cell numbers after shockwave application with a $5 \mathrm{~cm}$ distance from the applicator head are shown in Figure 3A. For an application rate of 100 impulses per cell culture flask, higher absolute viable cell numbers were measured in comparison to the control group at all tested frequencies however, only treatment with $1 \mathrm{~Hz}$ and $5 \mathrm{~Hz}$ reached statistical significance with both methods for cell viability measurements $(\mathrm{p}<0.05)$. The maximum viable cell count determined in the $\mathrm{LDH}$ assay was reached after 100 shockwave impulses at a frequency of $1 \mathrm{~Hz}(27.25 \%$, Figure 3B). The second highest value was detected at 100 impulses and $5 \mathrm{~Hz}(17.09 \%)$, whereas the lowest was detected at 25 impulses and $1 \mathrm{~Hz} 20.39 \%$ less than in control group.

At the distance of $6 \mathrm{~cm}$ from applicator head, differences in the absolute viable cell numbers could be seen with both methods and in
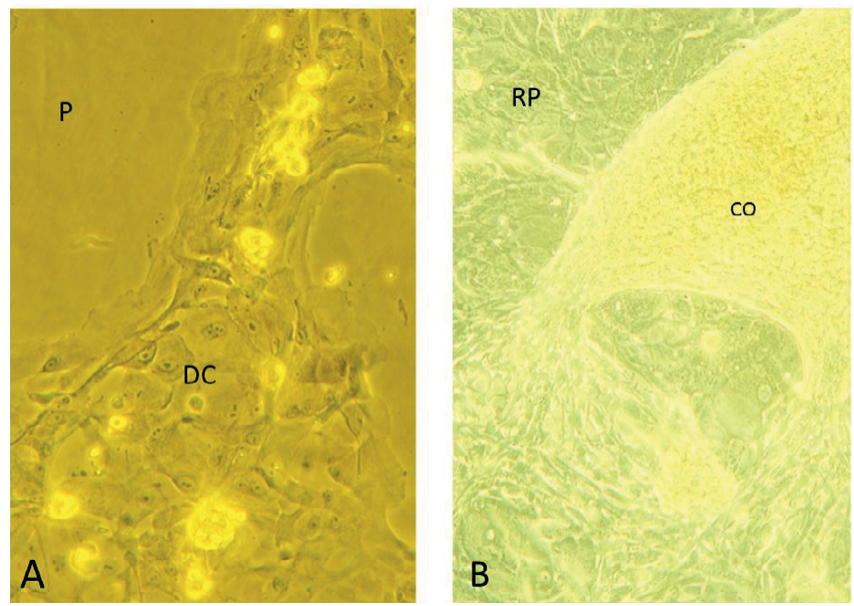

Figure 1: Representative images of perforation caused by ESWT treatment (A) and entirely repopulated perforation 7 days after ESWT (B). P- Perforation; DC- detached cells; RP- repopulated perforation; Magnification 100X.
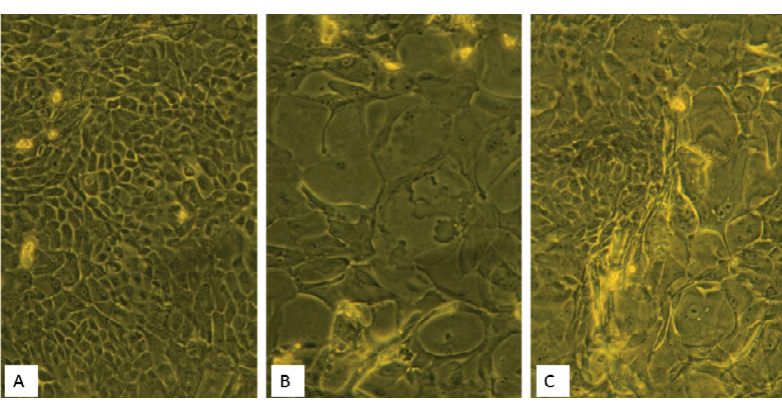

Figure 2: Light microscopy image of the human keratinocytes in ESWT exposed and control keratinocytes. ESWT treatment causes morphological changes in human keratinocytes in vitro. Acontrol group, untreated human keratinocytes are similar in shape and size. ESWT group was heterogeneous in size and shape (3C). Large oval cells were present in the area of cell detachment caused by ESWT (3B). Magnifications 100X.

\begin{tabular}{|c|c|}
\hline $\begin{array}{c}\text { Impulse number per flask, } \\
\text { frequency }\end{array}$ & $\begin{array}{c}\text { Diameter of the perforation } \\
\text { (macroscopic) }\end{array}$ \\
\hline $25 \mathrm{l} /$ flask, $1 \mathrm{~Hz}$ & $0 \mathrm{~cm}$ \\
\hline $25 \mathrm{l} /$ flask, $3 \mathrm{~Hz}$ & $0 \mathrm{~cm}$ \\
\hline $25 \mathrm{l} /$ flask, $5 \mathrm{~Hz}$ & $0 \mathrm{~cm}$ \\
\hline $50 \mathrm{l} /$ flask, $1 \mathrm{~Hz}$ & $0 \mathrm{~cm}$ \\
\hline $50 \mathrm{l} /$ flask, $3 \mathrm{~Hz}$ & $0 \mathrm{~cm}$ \\
\hline $50 \mathrm{l} /$ flask, $5 \mathrm{~Hz}$ & $0 \mathrm{~cm}$ \\
\hline $100 \mathrm{I} /$ flask, $1 \mathrm{~Hz}$ & $0 \mathrm{~cm}$ \\
\hline $100 \mathrm{I} /$ flask, $3 \mathrm{~Hz}$ & $0 \mathrm{~cm}$ \\
\hline $100 \mathrm{I} /$ flask, $5 \mathrm{~Hz}$ & $0.2 \mathrm{~cm}$ \\
\hline $300 \mathrm{I} /$ flask, $1 \mathrm{~Hz}$ & $0.3 \mathrm{~cm}$ \\
\hline $300 \mathrm{I} /$ flask, $3 \mathrm{~Hz}$ & $0.4 \mathrm{~cm}$ \\
\hline $300 \mathrm{l} /$ flask, $5 \mathrm{~Hz}$ & $0.5 \mathrm{~cm}$ \\
\hline $600 \mathrm{I} /$ flask, $1 \mathrm{~Hz}$ & $0.5 \mathrm{~cm}$ \\
\hline $600 \mathrm{I} /$ flask, $3 \mathrm{~Hz}$ & $0.6 \mathrm{~cm}$ \\
\hline $600 \mathrm{I} /$ flask, $5 \mathrm{~Hz}$ & $0.8 \mathrm{~cm}$ \\
\hline
\end{tabular}

Table 1: Formation of perforations in the cell monolayer with no attached cells after applications of shockwaves ata distance of $5 \mathrm{~cm}$ from the ESWT applicator. Number of impulses dependent and frequency dependent increasein the size of perforation area was observed. The diameter was measured from the longest diagonal.

treatments with different impulse numbers and frequencies. Differences in cell viability were both smaller and higher than in the control flasks (Figure 3C). Maximum detected viable cell count determined by LDH assay did not differ from control flasks (Figure 3D). Treatment settings of 25 impulses and $1 \mathrm{~Hz}$ had $26.1 \%$ lesser viable cells then control flasks. However, these differences failed to reach threshold for statistical significance.

Figure 3E shows the mean absolute viable cell numbers after shockwave application with a distance of $7 \mathrm{~cm}$ from the applicator head. For the flasks receiving the same number of impulses, there was increasein number of viable cells with increase in frequency. However, as a whole, these results were marginally below the cell number values measured in the control group. Significant difference was seen between 25 impulses group with frequency 3 and $5 \mathrm{~Hz}$, and in group that received 50 impulses at frequency of $5 \mathrm{Hzwhen}$ compared to the control flasks and all the 100 impulses flasks (Figure 3F).

\section{Keratinocyte metabolic activity before and after ESW}

In the time period before application, all experimental groups 
Citation: Ottomann CMD, Antonic V, Münch S, Belfekroun C, Niedobitek GMD, et al. (2015) In Vitro Effects of Extracorporeal Shockwave Therapy (ESWT) on Proliferation and Metabolic Activity of Adult Human Keratinocytes. J Bioengineer \& Biomedical Sci 5: 171. doi:10.4172/21559538.1000171
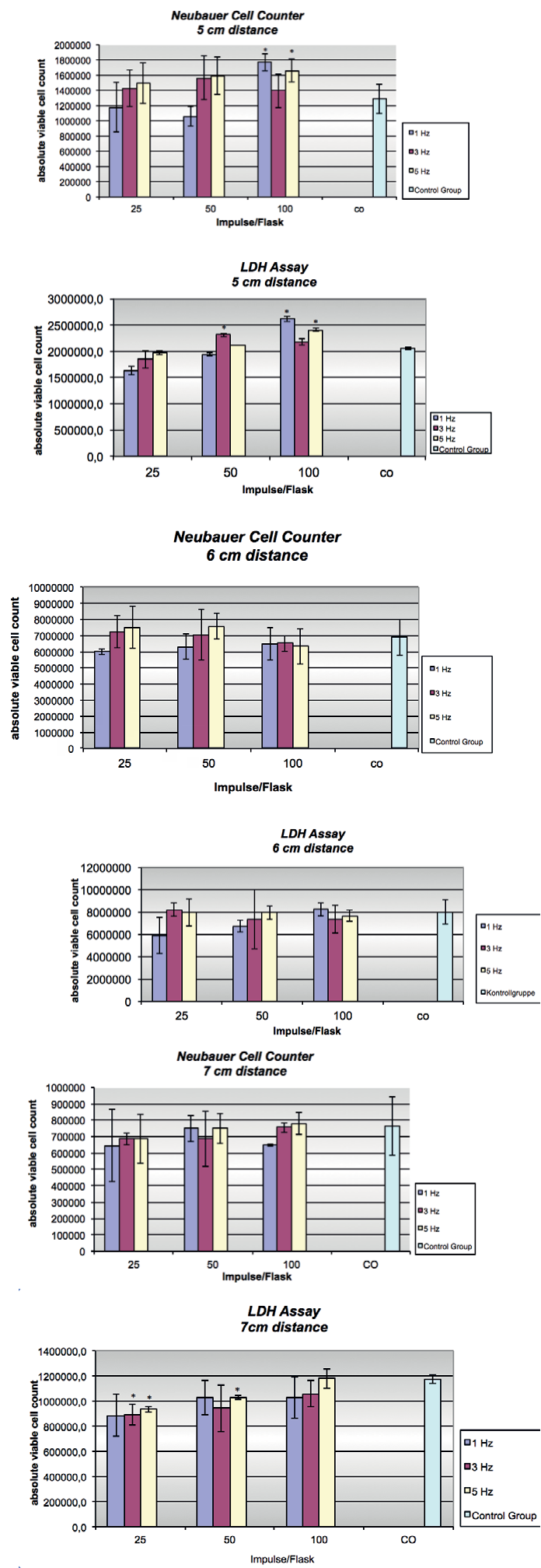

Figure 3: In vitro effects of various ESWT on cultured adult human keratinocytes. Cell viability was measured using trypan blue and directly counted in Neubauer chamber $(A, C, E)$ and using spectrophotometric $L D H$ release assay $(B, D, F)$. Results are presented as mean $+/-S D$ of 3 experiments. ${ }^{*} p<0.05$. 
Citation: Ottomann CMD, Antonic V, Münch S, Belfekroun C, Niedobitek GMD, et al. (2015) In Vitro Effects of Extracorporeal Shockwave Therapy (ESWT) on Proliferation and Metabolic Activity of Adult Human Keratinocytes. J Bioengineer \& Biomedical Sci 5: 171. doi:10.4172/21559538.1000171

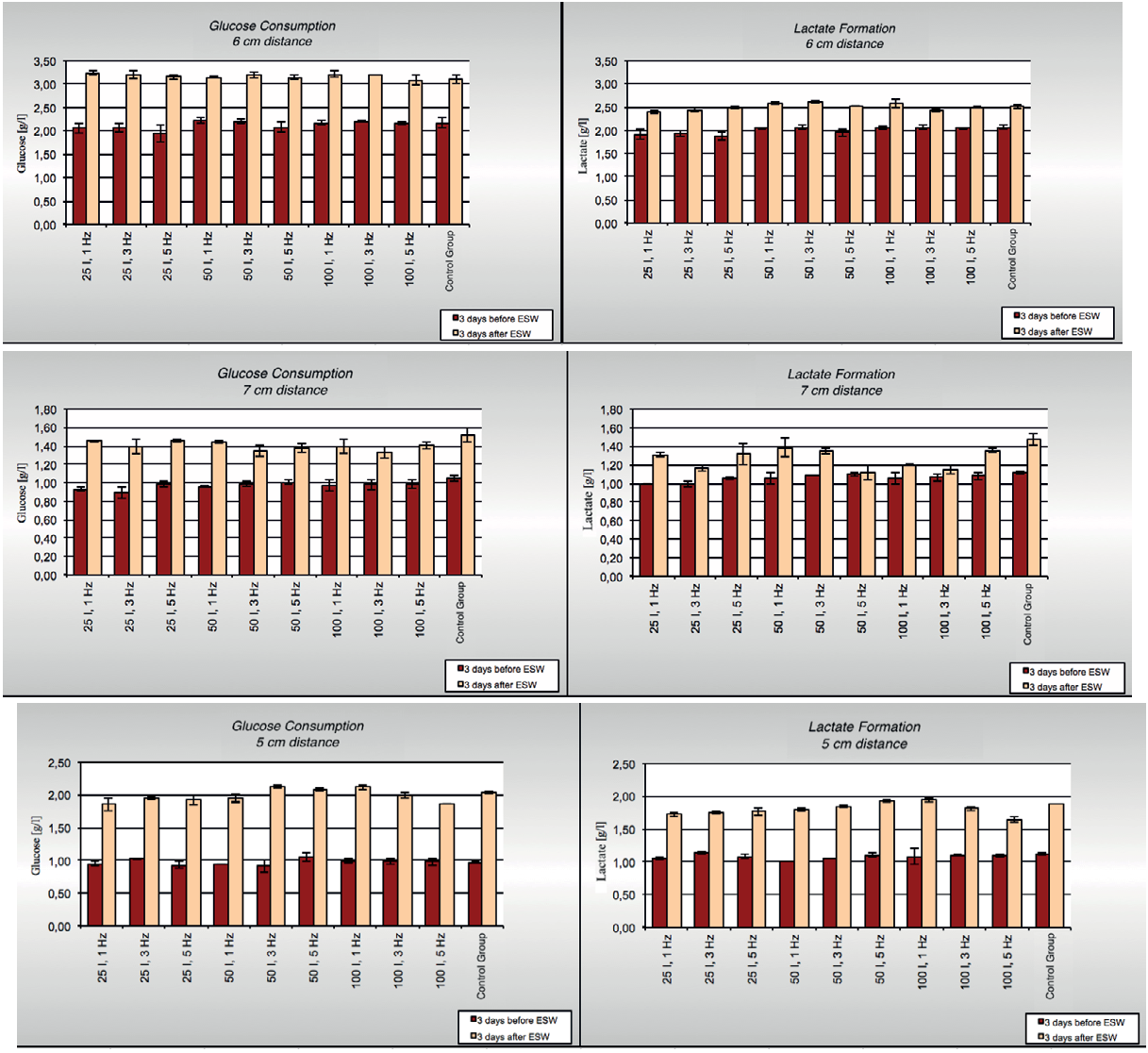

Figure 4: Treatment of human keratinocytes with ESWT causes dose- and frequency- dependent changes in metabolic activity of the treated cells 3 days after the treatment. Results are presented as summary of the experiments conducted using various treatment parameters $(25,50$ and 100 impulses at 1,3 and $5 \mathrm{~Hz})$ at same distance from the shockwave generator $5(A), 6(B)$ and $7 \mathrm{~cm}(C)$. All the results are presented as mean of 3 independent experiments $+/-S D$.

showed similar metabolic activities. At day 3 after ESWT increase in metabolic activity has been observed in all groups. At the distance of $5 \mathrm{~cm}$ higher consumption rates could be detected compared to the control group both in the group with 50 impulses at $3 \mathrm{~Hz}$ and in the group with 100 impulses at $1 \mathrm{~Hz}$ (Figure 4A, 4C and 4D). Despite the obvious differences, these values failed to reach threshold for statistical significance $(p>0.05)$. In the experimental flasks at distance of 6 and 7 $\mathrm{cm}$ from the applicator head, no metabolic effects have been observed when compared to controls. The lactate formation assay results showed similar trends (Figure 4B and 4D).

\section{Cytotoxic effect of extracorporeal shockwaves on keratino- cytes in vitro}

The results of the cell damage seen with the various investigated distances were quite inconsistent. For all the conducted experiments cytotoxicity was measured between $0-5 \%$. Even with these small differences some observations can be made: 1) highest cytotoxic effect had treatment with 25 impulses at $1 \mathrm{~Hz}$ and distance of $5 \mathrm{~cm}$ and 2) at distances $5 \mathrm{~cm}$ and $6 \mathrm{~cm}$ the highest $\mathrm{LDH}$ release was detected after 72 hours, whereas at $7 \mathrm{~cm}$ from the applicator head, the highest extracellular LDH activities were seen 15 minutes after ESWT (Figures $5 \mathrm{~A}-5 \mathrm{C})$.

\section{Discussion}

Effectiveness of the keratinocytes for the treatment of cutaneous wounds have been shown in the clinical settings as well as in animal models $[3,4,6]$. In order to continue investigations in this direction and develop allogenic keratinocytes for the clinical use, it is necessary to improve culturing protocols to promote proliferation without compromising keratinocytes capabilities to improve healing. The main objective of the presented study was to investigate effects of low energy ESWT on the keratinocyte culture in vitro. We used secondpassage subcultured keratinocytes, which are comparable to primary culture [30], and did not change due to high number of passages [31] and we also avoided immortalized keratinocyte cell lines as they were unsuitable for the question we were addressing. We were able to show that ESWT has significant dose- and frequency- dependent effects on the keratinocytes, ranging from cytotoxic to proliferation-stimulating effects.

In a previously published study, we have used 100 pulses with an energy flux density $0.1 \mathrm{~mJ} / \mathrm{mm}^{2}$ and a frequency of $1 \mathrm{~Hz}$ at a distance of $5 \mathrm{~cm}$ and showed using Ki-67 staining significant induction of proliferation and using IHC, promotion of mature phenotype [28]. Other authors used range 100-400 impulses applied to prostate carcinoma cells [27], 100 impulses for nerve cells [32], 50-500 impulses 
Citation: Ottomann CMD, Antonic V, Münch S, Belfekroun C, Niedobitek GMD, et al. (2015) In Vitro Effects of Extracorporeal Shockwave Therapy (ESWT) on Proliferation and Metabolic Activity of Adult Human Keratinocytes. J Bioengineer \& Biomedical Sci 5: 171. doi:10.4172/21559538.1000171
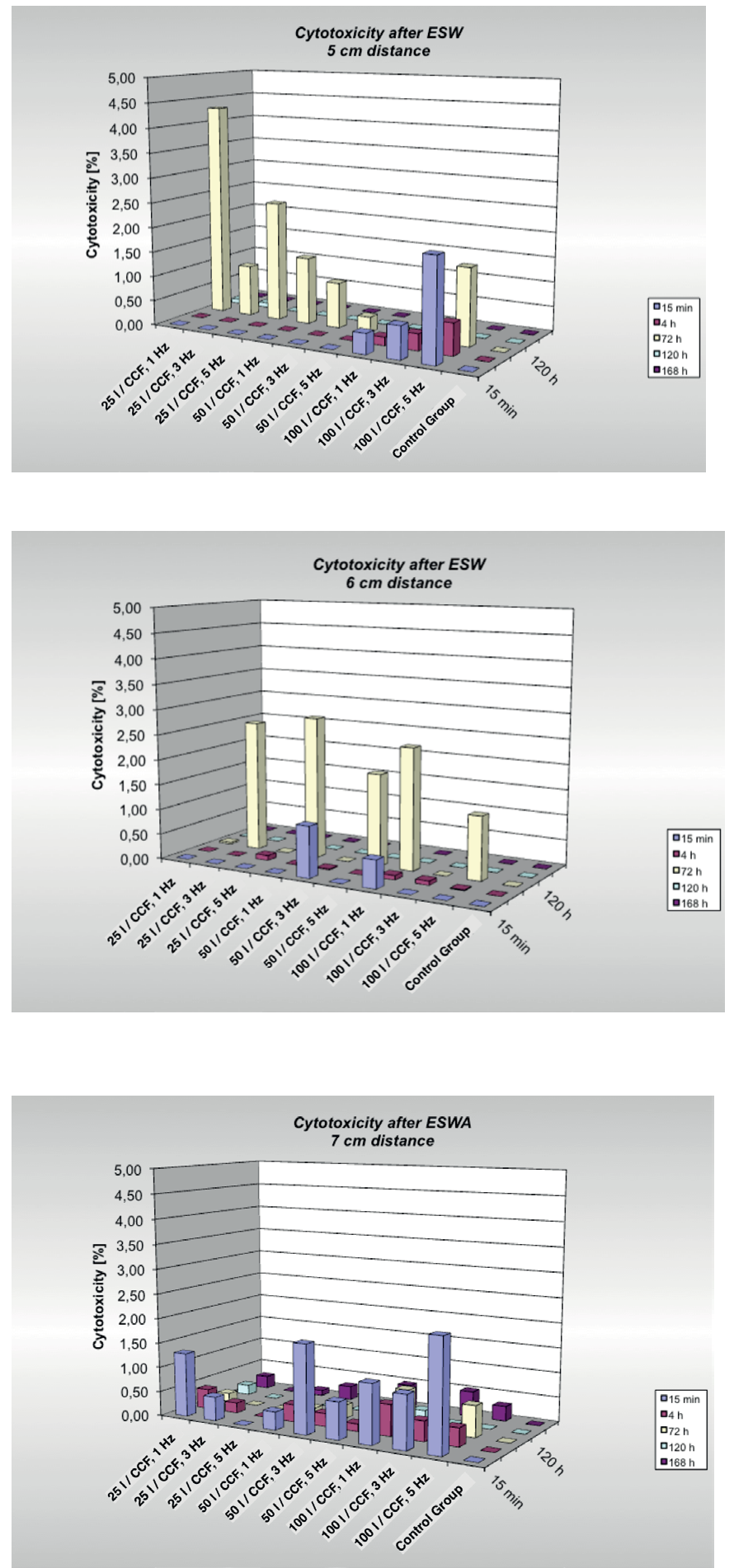

Figure 5: Cytotoxic effects of shockwave treatment $15 \mathrm{~min}, 4 \mathrm{~h}, 72 \mathrm{~h}, 120 \mathrm{~h}$ and $168 \mathrm{~h}$ after the exposure. Results are presented as mean $+/-$ SD of 3 separate experiments for one investigated distance. 
Citation: Ottomann CMD, Antonic V, Münch S, Belfekroun C, Niedobitek GMD, et al. (2015) In Vitro Effects of Extracorporeal Shockwave Therapy (ESWT) on Proliferation and Metabolic Activity of Adult Human Keratinocytes. J Bioengineer \& Biomedical Sci 5: 171. doi:10.4172/21559538.1000171

Page 7 of 8

for tenocytes [33] and 300 to 2000 impulses for fibroblasts [22]. For this study we therefore considered a range of 25-600 impulses to be appropriate, with an impulse number of 100 assumed as an optimum. Since only several publications on the effects of small impulse numbers are available, and taking into account that keratinocytes are generally considered sensitive, impulse numbers of 25 and 50 were included in the experimental setup. Groups receiving 300 and 600 impulses were examined to complete the total spectrum which has been analysed in studies conducted by others. Our results confirmed that from 500 impulses a significant reduction in the number of viable cells can be expected [23]. In our study, we have seen significant detachment of cells and large areas of the monolayer with no cells at dose of 300 impulses. Frequency of the application of the ESWT is of high importance for studying effects of shockwaves in vitro. Application of small number of impulses at higher frequencies has similar effects as application of a higher number of impulses at low frequency. This finding is in accordance with others [34,35]. Importantly, in the different experimental setup, using strain pressure perturbation also showed frequency dependant gene expression changes in human embryotic keratinocytes [36]. Combined, these findings are strongly advocating for the close monitoring of the frequency of mechanical stimuli, as well as optimisation of the frequency for achieving desired biological effects.

Our study had some limitations. Firstly, we have not investigated viability of the detached cells. In our study, first gaps in monolayer were observed in dose of 100 impulses applied at $5 \mathrm{~Hz}$, and prominent sizes with doses 300 and 600 impulses. Objective of presented study was to determine the most suitable treatment for the augmentation of keratinocyte proliferation, and as such, detached cells were of no interest. Other researchers investigated changes in membrane permeability after ESWT and showed that the free-floating cells still had an intact cell membrane, indicating that they were still viable and might even have been able to adhere once again [37]. Secondly, changes in cell membrane permeability can occur transiently without cells being killed, or permanently with cell structure disintegration [37]. Since detachment was observed in some experimental series (microscopical gaps with low number of impulses and large areas without cells in high number of impulses), it can be assumed that changes in permeability may have occurred, and that this could have effects on the cytotoxicity results (LDH release). Confirmatory counting of the viable cells was conducted in order to eliminate potential bias due to cell permeability. At doses beyond the macroscopically visible detachment threshold it can be reasoned that rupture of the cell membrane might have occurred.

\section{Conclusion}

Low-energy extracorporeal shockwaves have both a cytotoxic and stimulatory effect. These effects are dose-, energy flux density-number of applied impulses- and frequencies-, as well as distance, dependent. Proliferation-stimulating effect and a higher viable cell count are achieved at a distance of $5 \mathrm{~cm}$ with 100 impulses at $1 \mathrm{~Hz}$ and an energy flow density of $0.04 \mathrm{~mJ} / \mathrm{mm}^{2}$ and can be potentially used to promote keratinocyte proliferation in vitro. Further investigation of the ESWT effects with identified pro-proliferating effects on the keratinocytes proteomics and transcriptomics as well as their maturation are ongoing.

\section{References}

1. Rees RS, Adamson BF, Lindblad WJ (2001) Use of a cell-based interactive wound dressing to enhance healing of excisional wounds in nude mice. Wound Repair Regen 9: 297-304.

2. Morissette Martin P, Maux A, Laterreur V, Mayrand D, Gagné V L, et al. (2015) Enhancing repair of full-thickness excisional wounds in a murine model: Impact of tissue-engineered biological dressings featuring human differentiated adipocytes. Acta Biomater.

3. Moghaddam AS, Raji A, Movaffagh J, Yazdi AT, Mahmoudi M (2014) Effects of autologous keratinocyte cell spray with and without chitosan on third degree burn healing: an animal experiment. Wounds 26: 109-17.

4. Fratianne R, Papay F, Housini I, Lang C, Schafer IA (1993) Keratinocyte allografts accelerate healing of split-thickness donor sites: applications for improved treatment of burns. J Burn Care Rehabil 14: 148-54.

5. Lu G, Cai L, Zhao P, Gu Z, Zhu Y (2011) Mixed Suspension of Cultured Autologous and Allogenic Keratinocytes in Fibrin Glue for the Treatment of Fullthickness Burns. Wounds 23: 32-7.

6. Monstrey S, Beele H, Kettler M, Van Landuyt K, Blondeel P (1999) Allogeneic cultured keratinocytes vs. cadaveric skin to cover wide-mesh autogenous splitthickness skin grafts. Ann Plast Surg 43: 268-72.

7. Sood R, Roggy DE, Zieger MJ, Nazim M, Hartman BC (2015) A comparative study of spray keratinocytes and autologous meshed split-thickness skin graft in the treatment of acute burn injuries. Wounds 27: 31-40.

8. Silver FH, Siperko LM, Seehra GP (2003) Mechanobiology of force transduction in dermal tissue. Skin Res Technol 9: 3-23.

9. Reichelt $J$ (2007) Mechano transduction of keratinocytes in culture and in the epidermis. Eur J Cell Biol 86: 807-16.

10. Hofmann A, Ritz U, Hessmann MH, Alini M, Rommens PM (2008) Extracorporeal shock wave-mediated changes in proliferation, differentiation, and gene expression of human osteoblasts. J Trauma, 2008. 65(6): 1402-10.

11. Yano S, Komine M, Fujimoto M, Okochi H, Tamaki K (2004) Mechanica stretching in vitro regulates signal transduction pathways and cellular proliferation in human epidermal keratinocytes. J Invest Dermatol 122: 783-90.

12. Kippenberger S, Loitsch S, Guschel M, Müller J, Knies Y (2005) Mechanical stretch stimulates protein kinase B/Akt phosphorylation in epidermal cells via angiotensin II type 1 receptor and epidermal growth factor receptor. J Bio Chem 280: 3060-7.

13. Mittermayr R, Antonic V, Hartinger J, Kaufmann H, Redl H, et al. (2012) Extracorporeal shock wave therapy (ESWT) for wound healing: technology, mechanisms, and clinical efficacy. Wound Repair Regent 20: 456-65.

14. Antonic V, Mittermayr R, Schaden W, Stojadinovic A (2011) Evidence supporting extracorporeal shock wave therapy for acute and chronic soft tissue wounds. Wounds 2011 23: 204-15

15. Schaden W, Thiele R, Kölpl C, Pusch M, Nissan A, et al. Shock wave therapy for acute and chronic soft tissue wounds: a feasibility study. J Surg Res 143 $1-12$

16. Arno A, García O, Hernán I, Sancho J, Acosta A, et al. (2010) Extracorporeal shock waves, a new non-surgical method to treat severe burns. Burns 36: 844-9.

17. Davis TA, Stojadinovic A, Anam K, Amare M, Naik S, et al. (2009) Extracorporeal shock wave therapy suppresses the early pro inflammatory immune response to a severe cutaneous burn injury. Int Wound J 2009. 6: 11-21.

18. Ottomann C, Stojadinovic A, Lavin PT, Gannon FH, Heggeness MH, et al (2012) Prospective randomized phase II Trial of accelerated reepithelialization of superficial second-degree burn wounds using extracorporeal shock wave therapy. Ann Surg 255: 23-9.

19. Mittermayr R, Hartinger J, Antonic V, Meinl A, Pfeifer S, et al. (2011) Extracorporeal shock wave therapy (ESWT) minimizes ischemic tissue necrosis irrespective of application time and promotes tissue revascularization by stimulating angiogenesis. Ann Surg 253:1024-32.

20. Stojadinovic A, Elster EA, Anam K, Tadaki D, Amare M, et al. (2008) Angiogenic response to extracorporeal shock wave treatment in murine skin isografts. Angiogenesis 11: $369-80$

21. Yang G, Luo C, Yan X, Cheng L, Chai $Y$ (2011) Extracorporeal shock wave treatment improves incisional wound healing in diabetic rats. Tohoku J Exp Med 225: 285-92.

22. Berta, L, Fazzari A, Ficco AM, Enrica PM, Catalano MG, et al. (2009) Extracorporeal shock waves enhance normal fibroblast proliferation in vitro and activate mRNA expression for TGF-beta1 and for collagen types I and III. Acta Orthop 80: 612-7.

23. Gambihler S, Delius M, Brendel W (1990) Biological effects of shock waves: 
Citation: Ottomann CMD, Antonic V, Münch S, Belfekroun C, Niedobitek GMD, et al. (2015) In Vitro Effects of Extracorporeal Shockwave Therapy (ESWT) on Proliferation and Metabolic Activity of Adult Human Keratinocytes. J Bioengineer \& Biomedical Sci 5: 171. doi:10.4172/21559538.1000171

Page 8 of 8

cell disruption, viability, and proliferation of $L 1210$ cells exposed to shock waves in vitro. Ultrasound Med Biol 16: 587-94.

24. Leone, L, Vetrano M, Ranieri D, Raffa S, Vulpiani MC, et al. (2012) Extracorporeal Shock Wave Treatment (ESWT) improves in vitro functional activities of ruptured human tendon-derived tenocytes. PLoS One.

25. Raabe O, Shell K, Goessl A, Crispens C, Delhasse Y, et al. (2013) Effect of extracorporeal shock wave on proliferation and differentiation of equine adipose tissue-derived mesenchymal stem cells in vitro. Am J Stem Cells 2: 62-73.

26. Schuh CM, Heher P, Weihs AM, Banerjee A, Fuchs C, et al. (2014) In vitro extracorporeal shock wave treatment enhances stemness and preserves multipotency of rat and human adipose-derived stem cells. Cytotherapy 16: 1666-78.

27. Steinbach $\mathrm{P}$, Hofstädter F, Nicolai H, Rössler W, Wieland W (1992) In vitro investigations on cellular damage induced by high energy shock waves. Ultrasound Med Biol 18: 691-9.

28. Antonic V, Münch S, Belfekroun C, Niedobitek G, Petschke B, et al. (2015) Extracorporeal Shockwaves (ESWT) Promote Proliferation and Differentiation of Keratinocytes in Vitro - Histology and Immuno histochemistry. journal of bioengineering \& biomedical science 5: 1-5.

29. Holfeld J, Tepeköylü C, Kozaryn R, Mathes W, Grimm M, et al. (2014) Shock wave application to cell cultures. J Vis Exp (86).
30. Zare, S, Zarei MA, Ghadimi T, Fathi F, Jalili A, et al. (2014) Isolation, cultivation and transfection of human keratinocytes. Cell Biol Int, 38: 444-51.

31. Rasmussen C, Thomas-Virnig C, Allen-Hoffmann BL (2013) Classical human epidermal keratinocyte cell culture. Methods Mol Biol 945: 161-75.

32. Schelling, G, Delius M, Gschwender M, Grafe P, Gambihler S (1994) Extracorporeal shock waves stimulate frog sciatic nerves indirectly via a cavitation-mediated mechanism. Biophys J 66: 133-40.

33. Chao YH, Tsuang YH, Sun JS, Chen LT, Chiang YF, et al. (2008) Effects of shock waves on tenocyte proliferation and extracellular matrix metabolism. Ultrasound Med Biol 34: 841-52.

34. Ohl CD, Arora M, Ikink R, de Jong N, Versluis M, et al. (2006) Sonoporation from jetting cavitation bubbles. Biophys J 91: 4285-95.

35. Junge, L, Ohl CD. Wolfru B, Arora M, Ikink R (2003) Cell detachment method using shock-wave-induced cavitation. Ultrasound Med Biol 29: 1769-76.

36. Cherbuin T, Movahednia MM, Toh WS, Cao T (2014) Investigation of Human Embryonic Stem Cell-Derived Keratinocytes as an In Vitro Research Model for Mechanical Stress Dynamic Response. Stem Cell Rev 11: 460-473.

37. Ohl CD, Wolfrum B (2003) Detachment and sonoporation of adherent HeLacells by shock wave-induced cavitation. Biochim Biophys Acta 1624: 131-8. 